\title{
INTERACTIONS OF SAFLUFEnACIL WiTH OTHER HERBICIDES Promoters of OXIDATIVe STREss to Control Joyweed ${ }^{1}$
}

\author{
Interações de Saflufenacil com Outros Herbicidas Promotores de Estresse Oxidativo para o \\ Controle de Apaga-Fogo
}
TREZZI, M.M. ${ }^{2}$, DIESEL, F. ${ }^{2}$, KRUSE, N.D. ${ }^{3}$, XAVIER, E. ${ }^{2}$, PAZUCH, D. ${ }^{2}$, PAGNONCELLI JR., F. ${ }^{2}$, and BATISTEL, S.C. ${ }^{2}$

\begin{abstract}
This study was conducted to evaluate the efficacy of joyweed (Alternanthera tenella) control and antagonistic or synergistic potentials of saflufenacil herbicide applied alone or tank mixed with paraquat, metribuzin and clomazone. The experiment was conducted in a greenhouse in a completely randomized design with four replications. Treatments consisted of saflufenacil herbicide doses $\left(0,0.4,0.7,1.4,2.1\right.$ and $\left.2.8 \mathrm{~g} \mathrm{ha}^{-1}\right)$ applied isolated or associated with paraquat $\left(0,1\right.$ and $\left.3 \mathrm{~g} \mathrm{ha}^{-1}\right)$, metribuzin $\left(0,38.4\right.$ and $\left.105.6 \mathrm{~g} \mathrm{ha}^{-1}\right)$ or clomazone $\left(0,288\right.$ and $\left.504 \mathrm{~g} \mathrm{ha}^{-1}\right)$. Visual control was determined at 14 and 21 days after spraying the herbicides (DAA) and shoots dry matter at 21 DAA. Colby's method was used to calculate the response from herbicide interactions. Saflufenacil associations with paraquat and metribuzin were promising to control $A$. tenella, due to the high levels of control achieved and because they demonstrated compatibility, especially in some combinations. Tank mixing saflufenacil with clomazone was not promising for the control of A. tenella due to the low efficacy of joyweed control and because it demonstrated herbicide incompatibility.
\end{abstract}

Keywords: Alternanthera tenella, tank mixture, protox inhibitors, photosystem I inhibitors, photosystem II inhibitors, carotenoids synthesis inhibitors.

RESUMO - Este estudo foi conduzido para avaliar a eficácia de controle da espécie daninha apagafogo (Alternanthera tenella) e o potencial antagônico ou sinérgico das associações de saflufenacil com paraquat, metribuzin e clomazone. O experimento foi realizado em vasos, em casa de vegetação, em delineamento inteiramente casualizado com quatro repetições. Os tratamentos foram constituídos de doses do herbicida saflufenacil $\left(0,0,35,0,7,1,4,2,1\right.$ e 2,8 $\left.\mathrm{g} \mathrm{ha}^{-1}\right)$ aplicadas de forma isolada ou associadas ao paraquat (0, 1 e $\left.3 \mathrm{~g} \mathrm{ha}^{-1}\right)$, metribuzin $\left(0,38,4\right.$ e 105, $\left.6 \mathrm{~g} \mathrm{ha}^{-1}\right)$ ou clomazone (0, 288 e $\left.504 \mathrm{~g} \mathrm{ha}^{-1}\right)$. Foram determinados o controle visual aos 14 e 21 dias após a aplicação (DAA) dos herbicidas e a matéria seca da parte aérea das plantas aos 21 DAA. O método de Colby foi utilizado para o cálculo da resposta esperada da interação entre os herbicidas. As associações de saflufenacil com paraquat e metribuzin foram promissoras no controle de $\boldsymbol{A}$. tenella, pela elevação dos niveis de controle e pela compatibilidade demonstrada entre os herbicidas, especialmente em algumas combinações. A associação entre saflufenacil e clomazone não foi promissora para o controle de A. tenella, em razão dos baixos niveis de controle e da incompatibilidade entre os herbicidas.

Palavras-chave: Alternanthera tenella, associações de herbicidas, inibidores da Protox, inibidores do fotossistema I, inibidores do fotossistema II, inibidores da síntese de carotenóides.

\section{INTRODUCTION}

Joyweed (Alternanthera tenella) is a weed belonging to the Amaranthaceae family, a perennial that reproduces sexually. Also, it is characterized by vigorous growth, with dominance over other species in the field (Moreira \& Bragança, 2010).

1 Recebido para publicação em 3.8.2015 e aprovado em 26.8.2015.

2 Universidade Tecnológica Federal do Paraná (UTFPR), Pato Branco, PR, Brasil,<trezzim@gmail.com>; ${ }^{3}$ Departamento de Defesa Fitossanitária, CCR, UFSM, Santa Maria, RS, Brasil. 
The simultaneous use of two or more herbicides has been increasingly practiced in agriculture and represents advances in weed control strategies, providing multiple benefits such as reducing the number of pesticide spraying operations in cultivated areas and expansion of the weeds control spectrum (Gressel, 1990). The combination of herbicides with different mechanisms of action may result in synergistic, antagonistic or additive effects (Colby, 1967). Associations which result in synergism arouse interest as they allow to improve control or the use of lower doses, which represents production costs reduction. Instead, associations that produce antagonism can result in hindering herbicides performance, requiring dose increase, leading to higher production costs or requiring herbicide application separately (Kruse et al., 2001; Trezzi et al., 2007).

Saflufenacil herbicide inhibits the enzyme protoporphyrinogen IX oxidase (Protox) (Grossmann et al., 2010) and has recently been registered in Brazil. While performing action through mechanisms of action that are different from saflufenacil, herbicides paraquat, metribuzin and clomazone are also promoters of oxidative stress in plants, leading to lipid peroxidation and irreversible damage to cell membranes (Hess, 2000).

There are few studies investigating the association of Protox-inhibiting herbicides with herbicides that have a similar action and can be employed at the time of burndown weeds. The interaction of photosystem II (metribuzin) and carotenoid synthesis (clomazone) inhibitors was antagonistic to control Abutilon theophrasti and synergistic to control Bidens pilosa, indicating that the response can be specific for each species (Kruse et al., 2001).

The objective of this study was to evaluate the effectiveness of joyweed (Alternanthera tenella) control and the potential for antagonism or synergism of saflufenacil associations with paraquat, metribuzin and clomazone.

\section{MATERIALS AND METHODS}

Three experiments were conducted in a greenhouse at the Federal Technological
University of Paraná (UTFPR), Pato Branco Campus. The soil used, classified as distroferric red latosol (Bhering et al., 2008), was collected at Experimental Area of the Federal Technological University of Paraná

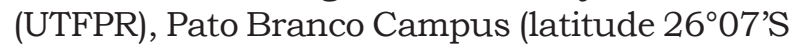
and longitude $52^{\circ} 41^{\prime} \mathrm{W}$ ) sieved and deposited in pots with a capacity of $9 \mathrm{dm}^{3}$. Studies were conducted in a completely randomized design with four replications.

Joyweed (A. tenella) seeds were sown in a depth of 1 a $2 \mathrm{~cm}$. Twenty days after sowing, thinning was carried out, leaving three plants per repetition. Treatments consisted of herbicide doses of saflufenacil $(0 ; 0.35 ; 0.7 ; 1.4$; 2.1 and $2.8 \mathrm{~g} \mathrm{ha}^{-1}$ ) applied in isolation or in combination with paraquat $\left(0,1\right.$ and $\left.3 \mathrm{~g} \mathrm{ha}^{-1}\right)$ in the first experiment; metribuzin $(0,38.4$ and $\left.105.6 \mathrm{~g} \mathrm{ha}^{-1}\right)$ in the second one; and clomazone $\left(0,288\right.$ and $\left.504 \mathrm{~g} \mathrm{ha}^{-1}\right)$ in the third one. Adjuvant Dash $\mathrm{HC}^{\circledR}$ at $0.5 \%$ (v/v) was added to the treatments. The doses were selected by preliminary experiments of doses response in order to determine those that resulted in lower levels of control than $100 \%$, which is an analysis assumption of the interaction among the herbicides. The selected doses were lower than the commercial products label recommendations. Application was postemergence, in plants with six to eight fully expanded leaves. Herbicides were sprayed employing $\mathrm{CO}_{2}$ backpack sprayer pressurized with $\mathrm{CO}_{2}$ kept at a constant pressure, with XR 110.02 fan-type nozzle tips, spaced $0.50 \mathrm{~m}$ apart in a boom measuring $1.5 \mathrm{~m}$ wide, totaling a spray solution volume of $200 \mathrm{~L} \mathrm{ha}^{-1}$. The application began at 5:45 pm, with air temperature of $27^{\circ} \mathrm{C}$, air relative humidity of $66 \%$ and average wind speed of $1.1 \mathrm{~m} \mathrm{~s}^{-1}$, and it finished at 7:30 pm, with a temperature of $25{ }^{\circ} \mathrm{C}$, air relative humidity of $75 \%$ and average wind speed of $1 \mathrm{~m} \mathrm{~s}^{-1}$.

Visual control percentage determinations were performed at 14 and 21 days after application (DAA) of the treatments using the scale proposed by Frans et al. (1986), where $0 \%$ represents no effect of the herbicides on plants and $100 \%$ represents total plant death. At the end of the experiment, at 21 DAA, the plants were dried at $60^{\circ} \mathrm{C}$ until constant mass, and then the shoots dry matter (DMS) was determined. 
Percent data of control and shoot dry matter of isolated treatments were submitted to Colby's method (1967). The equation used to calculate the expected response in the interaction of saflufenacil with paraquat, metribuzin and clomazone was:

$$
\mathrm{E}=100-((100-\mathrm{X}) *(100-\mathrm{Y})) / 100
$$

where $\mathrm{E}=$ estimated effect; $\mathrm{X}=$ effect observed by herbicide $\mathrm{X}$; and $\mathrm{Y}=$ effect observed by herbicide Y.

The differences of effects (expected and observed) were compared by the t-test at $5 \%$ of significance $(p<0.05)$. Data from visual control and MPAS were initially submitted to analysis of variance by the $\mathrm{F}$-test and complemented by regression analysis. Subsequently, data were adjusted using primarily the four-parameter logistic equation $\left(y=d+\left((a-d) /\left(\left(1+(x / c)^{b}\right)\right)\right.\right.$ and, secondly, the three-parameter sigmoidal $(y=a /(1+\exp (-(x-x 0) / b)))$, where: $y=$ dependent variable; $x=$ concentration of the herbicide; $\mathrm{a}=$ average of the control response; $\mathrm{b}=$ curve slope $\mathrm{c}=$ concentration that provides a $50 \%$ reduction of the dependent variable value $\left(I_{50}\right)$; and $d=$ response average under high doses.

\section{RESULTS AND DISCUSSION}

Analyses of variance of the three experiments for all variables studied were significant at the $5 \%$ level for interaction between herbicides versus doses. With the equations adjustment, $R^{2}$ values obtained were between 0.82 and 0.99 .

Rising saflufenacil doses, applied in isolation, resulted in increased percentage of joyweed control, reaching maximum values between 73 and $66 \%$ at 14 and 21 DAA, respectively, with the highest dose applied (2.8 $\mathrm{g} \mathrm{ha}^{-1}$ ) (Figures $1 \mathrm{~A}$ and B). Paraquat association (1 and $3 \mathrm{~g} \mathrm{ha}^{-1}$ ) to saflufenacil resulted in significant increase in this species control compared to standalone application, reaching maximum levels of 93 and $78 \%$ in the association of $2.8 \mathrm{~g} \mathrm{ha}^{-1}$ of saflufenacil + $1 \mathrm{~g} \mathrm{ha}^{-1}$ of paraquat and 95 and $86 \%$ in the association $2.8 \mathrm{~g} \mathrm{ha}^{-1}$ of saflufenacil $+3 \mathrm{~g} \mathrm{ha}^{-1}$ of paraquat for both periods evaluated, respectively. At $21 \mathrm{DAA}$, only the combination employing two higher doses of both herbicides $\left(2.8+3 \mathrm{~g} \mathrm{ha}^{-1}\right)$ resulted in satisfactory levels of control (> 80\%).

Studies on the efficacy of paraquat alone $\left(702 \mathrm{~g}\right.$ a.i. $\left.\mathrm{ha}^{-1}\right)$ or associates with saflufenacil $\left(0 ; 6.3 ; 12.5 ; 25\right.$ and $50 \mathrm{~g}$ a.i. ha $\left.{ }^{-1}\right)$ on horseweed (C. canadensis) were carried out by Waggoner et al. (2011). In that study, in the evaluations done at 7 and 30 DAA, paraquat alone showed control of 84 and $70 \%$, and the association of saflufenacil + paraquat $\left(6.3 \mathrm{~g}+702 \mathrm{~g}\right.$ a.i. $\left.\mathrm{ha}^{-1}\right)$ resulted in control of $81 \%$, but higher doses of saflufenacil ( 25 or $50 \mathrm{~g}$ a.i. $\mathrm{ha}^{-1}$ ) associated to paraquat resulted in control levels of 96 and $83 \%$, respectively. In this study, the use of lower doses of paraquat and saflufenacil (isolated or associated) resulted in a satisfactory control of joyweed, which shows the lower sensitivity of this species, compared to horseweed (C. canadensis).

Considering the different combinations of saflufenacil and paraquat (Figures $1 \mathrm{~A}$ and $\mathrm{B}$ ), the only ones that demonstrated differences between the expected values and control values obtained in the practice were the combinations of $2.1 \mathrm{~g}$ of saflufenacil with any of the paraquat doses used ( 1 or $3 \mathrm{~g} \mathrm{ha}^{-1}$ ) at 14 and $21 \mathrm{DAA}$, indicating a synergistic interaction between the herbicides. All other combinations showed no difference between expected and observed effects. A likely explanation for the synergistic effect occurring only with paraquat association with one of the highest doses of saflufenacil could be in the occurrence of saflufenacil translocation potentiation in higher doses, which could overcome the negative effect of damage caused by paraquat.

The association of saflufenacil to the lowest dose of metribuzin (38.4 $\mathrm{g} \mathrm{ha}^{-1}$ ) has not resulted in a significant increase of joyweed control compared to the isolated application of saflufenacil, except for the dose of $2.1 \mathrm{~g} \mathrm{ha}^{-1}$ of saflufenacil (Figures 1C and D). However, saflufenacil associations with the highest dose of metribuzin (105.6 $\mathrm{g} \mathrm{ha}^{-1}$ ) resulted in a significant increase in control levels of this weed regarding the application of saflufenacil alone. At 21 DAA, only two combinations which employ higher doses of both herbicides $\left(2.1+105.6\right.$ and $\left.2.8+105.6 \mathrm{~g} \mathrm{ha}^{-1}\right)$ resulted in satisfactory control levels (Figures $1 \mathrm{C}$ and D). 

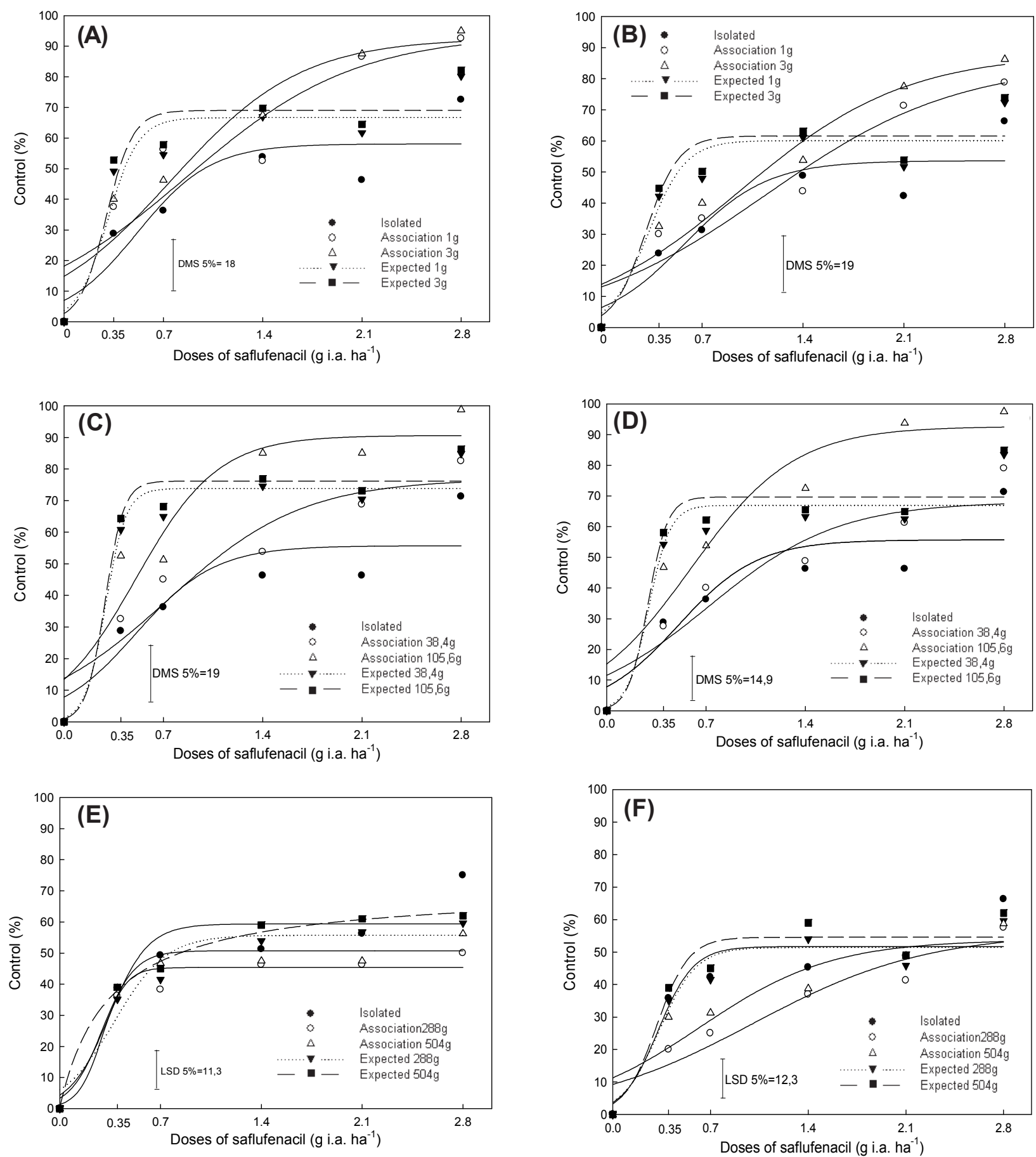

Figure 1 - Alternanthera tenella control percentages in response to the application of saflufenacil doses isolated and associated with herbicides paraquat at 14 (A) and 21 DAA (B), metribuzin at 14 (C) and 21 DAA (D) and clomazone at 14 (E) and 21 DAA (F).

In the association between saflufenacil and metribuzin, in general, no differences were detected between the expected and observed control percentages (Figures 1C and D). Only in the associations of 0.35 and $0.7 \mathrm{~g} \mathrm{ha}^{-1}$ of saflufenacil $+38.4 \mathrm{~g} \mathrm{ha}^{-1}$ of metribuzin, the expected results exceeded the actual ones, both at 14 and at 21 DAA, 
indicating, in such cases, an antagonism for the control percentage variable. Frihauf et al. (2010) have observed that wheat plants absorbed 2.8 to 3.5 times more saflufenacil when combined with the herbicide 2,4dichlorophenoxyacetic acid compared to isolated saflufenacil; however, when saflufenacil was associated with bentazon, also an PSII (Photosystem II) inhibitor as metribuzin, there was a $6 \%$ reduction in its absorption. Thus, it is possible that the antagonistic effect generated by the PSII-inhibitor, identified in lower doses of saflufenacil, is being overcome with the rise of doses of the Protox-inhibitor.

Saflufenacil associations to any doses of clomazone (288 or $504 \mathrm{~g} \mathrm{ha}^{-1}$ ) have not resulted in a significant increase in control levels of A. tenella compared to the isolated application of saflufenacil (Figures $1 \mathrm{E}$ and F). Conversely, the association of lower doses of saflufenacil ( 0.7 and $1.4 \mathrm{~g} \mathrm{ha}^{-1}$ ) to the lowest dose of clomazone (288 $\left.\mathrm{g} \mathrm{ha}^{-1}\right)$ has sometimes resulted in lower control levels than those obtained with the isolated application of saflufenacil at 21 DAA (Figure 1F). Only these combinations at 21 DAA showed an antagonistic effect among the herbicides.

Antagonistic interactions of this association may be related to the different biological behavior of the herbicides used. Although carotenoid synthesis inhibitors are capable of translocation in the plants xylem (Kruse et al., 2001), saflufenacil is able to translocate both by the phloem as the xylem (Grossmann et al., 2010), displays faster action than clomazone and may limit clomazone translocation in joyweed plants. According to Ashigh and Hall (2010), there is more contact action of saflufenacil when mixed with an adjuvant, which could affect the action of systemic herbicides in combination, compared to the application without adjuvant.

The MPAS reductions of $A$. tenella plants with rising saflufenacil doses alone have reached $63 \%$ for the lowest dose $\left(0.35 \mathrm{~g} \mathrm{ha}^{-1}\right)$ and $85 \%$ for the highest dose $\left(2.8 \mathrm{~g} \mathrm{ha}^{-1}\right)$ (Figures 2A, B and C). The treatments which combined $0.7,1.4$ and $2.1 \mathrm{~g}$ of saflufenacil with $3 \mathrm{~g}$ of paraquat resulted in higher reduction in MPAS comparing to saflufenacil alone (Figure 2A), while few differences were found comparing with the combination with the lowest dose of paraquat ( $\left.1 \mathrm{~g} \mathrm{ha}^{-1}\right)$.

Saflufenacil association with metribuzin was the one resulting in greater MPAS reductions, compared to the association with paraquat or clomazone, with differences in relation to saflufenacil alone in virtually all doses of the Protox inhibitor. The greatest decreases were obtained with the use of higher doses of saflufenacil (Figure 2B).

Plants treated with saflufenacil associated with clomazone (Figure 2C) showed less significant reduction in MPAS compared to associations with paraquat and metribuzin, showing similar behavior to the saflufenacil application alone. Saflufenacil alone in the highest dose $\left(2.8 \mathrm{~g} \mathrm{ha}^{-1}\right)$ showed more significant reduction of MPAS than the associations with clomazone (Figure 2C).

The MPAS results analyzed using the Colby's method showed a synergistic interaction for all combinations of saflufenacil com paraquat, metribuzin and clomazone (Table 1). The synergistic interactions for weed control are considered advantageous, because they improve the control levels of weed species and allow the use of smaller doses and product applications in combination, which may mean reducing the applications costs. However, saflufenacil associations to other herbicides can result in synergism also for the cultivated species, increasing the injury and reducing grain yield, which happened to the soybean crop in the experiment where saflufenacil was associated with early growth inhibitory herbicides (Mahoney et al., 2014). However, the present study has not assessed the effect of associations on cultivated plants and could represent a new demand for studies.

The results show differences between variables control percentage and MPAS regarding the types of interactions detected by the Colby's method. This is probably because the visual control analysis considers symptoms such as chlorosis and necrosis and shows signs of plant development recovery (regrowth), besides the reduction in its development, which is quantified in assessing the MPAS. Thus, the visual control analysis, although it has a higher degree of subjectivity, adds other important components for the evaluation of herbicidal effectiveness. 

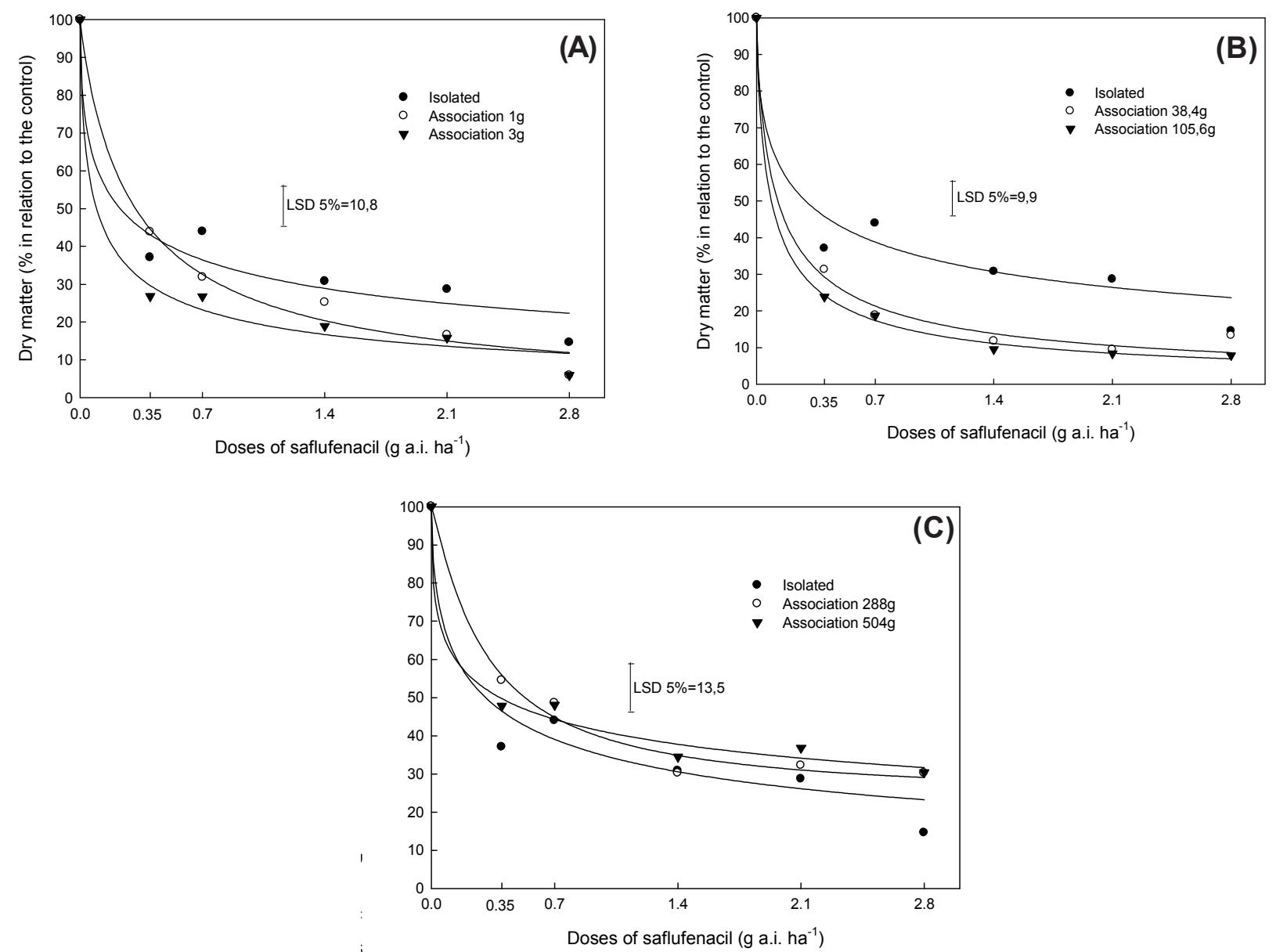

Figure 2 - Shoots dry matter of Alternanthera tenella in response to the application of saflufenacil doses of isolated and associated with two doses of paraquat (A), metribuzin (B) and clomazone (C).

Table 1 - Interaction analysis of herbicides saflufenacil and paraquat (A), saflufenacil and metribuzin (B) and saflufenacil and clomazone (C) for variable shoots dry matter of Alternanthera tenella

\begin{tabular}{|c|c|c|c|c|c|c|c|c|c|c|c|}
\hline \multirow{2}{*}{$\begin{array}{c}\text { Saflufenacil } \\
+ \text { Paraquat } \\
\text { (g) }\end{array}$} & \multicolumn{2}{|c|}{ Dry matter $(\%)$} & \multirow{2}{*}{$\begin{array}{c}P \\
5 \%\end{array}$} & \multirow{2}{*}{$\begin{array}{l}\text { Saflufenacil } \\
+ \text { Metribuzin } \\
\text { (g) }\end{array}$} & \multicolumn{2}{|c|}{ Dry matter $(\%)$} & \multirow{2}{*}{$\begin{array}{c}P \\
5 \%\end{array}$} & \multirow{2}{*}{$\begin{array}{l}\text { Saflufenacil } \\
+ \text { Clomazone } \\
\text { (g) }\end{array}$} & \multicolumn{2}{|c|}{ Dry matter $(\%)$} & \multirow{2}{*}{$\begin{array}{c}P \\
5 \%\end{array}$} \\
\hline & Exp. & Obs. & & & Exp. & Obs. & & & Exp. & Obs. & \\
\hline $0.35+1$ & 57.04 & 43.85 & $*$ & $0.35+38.4$ & 51.99 & 31.29 & $*$ & $0.35+288$ & 76.61 & 54.45 & $*$ \\
\hline $0.7+1$ & 61.91 & 31.88 & $*$ & $0.7+38.4$ & 57.37 & 18.77 & $*$ & $0.7+288$ & 79.26 & 48.6 & $*$ \\
\hline $1.4+1$ & 52.7 & 25.21 & $*$ & $1.4+38.4$ & 47.01 & 11.79 & $*$ & $1.4+288$ & 74.29 & 30.18 & $*$ \\
\hline $2.1+1$ & 51.35 & 16.59 & $*$ & $2.1+38.4$ & 45.38 & 9.49 & $*$ & $2.1+288$ & 73.6 & 32.21 & $*$ \\
\hline $2.8+1$ & 41.89 & 5.91 & $*$ & $2.8+38.4$ & 34.63 & 13.3 & $*$ & $2.8+288$ & 68.5 & 30.18 & $*$ \\
\hline $0.35+3$ & 54.82 & 26.84 & $*$ & $0.35+05.6$ & 49.93 & 23.89 & $*$ & $0.35+504$ & 77.38 & 47.82 & $*$ \\
\hline $0.7+3$ & 59.38 & 26.76 & $*$ & $0.7+105.6$ & 55.52 & 18.67 & $*$ & $0.7+504$ & 79.97 & 39.06 & $*$ \\
\hline $1.4+3$ & 50.25 & 18.92 & $*$ & $1.4+105.6$ & 44.87 & 9.5 & $*$ & $1.4+504$ & 75.07 & 34.46 & $*$ \\
\hline $2.1+3$ & 48.52 & 15.83 & $*$ & $2.1+105.6$ & 43.17 & 8.35 & $*$ & $2.1+504$ & 74.32 & 36.81 & $*$ \\
\hline $2.8+3$ & 38.36 & 5.91 & $*$ & $2.8+105.6$ & 31.73 & 7.89 & $*$ & $2.8+504$ & 69.22 & 30.4 & $*$ \\
\hline
\end{tabular}

Exp.: expected; Obs.: observed. 
These differences were also detected in the study conducted by Dalazen (2012), which aimed to evaluate the effect of different doses of herbicides glyphosate and saflufenacil in standalone and in combination applications, on the control of horseweed plants. In this study, the authors have found that the association $1,280 \mathrm{~g}$ a.e. ha-1 ${ }^{-1}$ of glyphosate + $1.09 \mathrm{~g}$ a.i. ha ${ }^{-1}$ of saflufenacil obtained an antagonistic effect for the variable visual control and a synergistic effect to reduce MPAS.

According to Zhang et al. (1995), the possibility of occurring synergistic or antagonistic interactions in association with herbicides with different mechanisms of action is the same. Although for Streibig et al. (1981) synergism is not expected in mixtures of herbicides with a similar mode of action, in the present study, synergistic effects were observed for some associations of saflufenacil with paraquat and metribuzin.

The results of this study indicate that the association of saflufenacil with herbicides paraquat and metribuzin is promising in the control of A. tenella, because for many combinations there was compatibility among the herbicides, demonstrated by the additive or synergistic effects. The possibility of association of two herbicides in the same application can be advantageous for farmers in many ways, among which stand out: reduction in time to implement the control operation; increased control spectrum of weeds because there is variation among herbicides as to a particular weed control efficiency; smashing reduction caused during spraying; improved efficiency; and the possibility of reducing herbicide dose used in case of synergism. The need to study the physiological basis of action of these herbicides on A. tenella is raised to investigate the behavior of associations used in this study and thus elucidate possible changes in the herbicides absorption and translocation.

The results of this study indicate that saflufenacil associations with herbicides paraquat and metribuzin are promising in controlling Alternanthera tenella by the high levels of control and the compatibility demonstrated among the herbicides, showing synergism. Associations between saflufenacil and clomazone are not promising for the control of $A$. tenella, because the associations show antagonism.

\section{LITERATURE CITED}

ASHIGH, J. J.; HALL, C. Bases for Interactions between saflufenacil and glyphosate in plants. J. Agric. Food Chem., v. 58, n. 12 , p. $7335-7343,2010$.

BHERING S. B. et al. Mapa de solos do Estado do Paraná: legenda atualizada. Rio de Janeiro: EMBRAPA/IAPAR, 2008. $74 \mathrm{p}$.

COLBY, S. R. Calculating synergistic and antagonistic responses of herbicide combinations. Weed Sci. Soc. Am., v. 15, n. 1 , p. 20-22, 1967.

DALAZEN, G. Estratégias de controle e artropodofauna de buva (Conyza bonariensis) associada em lavoura de soja e em pastagem de inverno. 2012. 101 f. Dissertação (Mestrado em Agronomia) - Universidade Federal de Santa Maria, Santa Maria, 2012.

FRANS, R. et al. Experimental design and techniques for measuring and analyzing plant responses to weed control practices. In: CAMPER, N. D. Research methods in weed science. 3.ed. Champaign: Southern Weed Science Society, 1986. p. 29-46.

FRIHAUF, J. C. et al. Winter wheat and weed response to postemergence saflufenacil alone and in mixtures.

Weed Technol., v. 24, n. 3, p. 262-268, 2010.

GRESSEL, J. Synergizing herbicides. Rev. Weed Sci., v. 5, p. 49-82, 1990.

GROSSMANN, K. et al. The herbicide saflufenacil (KixorTM) is a new inhibitor of protoporphyrinogen IX oxidase activity. Weed Sci., v. 58, n. 1, p. 1-9, 2010.

KRUSE, N. D. et al. Sinergismo potencial entre herbicidas inibidores do Fotossistema II e da síntese de carotenóides. Ci. Rural, v. 31, n. 4, p. 569-575, 2001.

MAHONEY, K. J. et al. Tolerance to soybean (Glycine $\max \mathrm{L}$.) to protoporphyrionogen oxidase inhibitors and very long chain fatty acids synthesis inhibitors applied herbicides. Am. J. Plant Sci., v. 5, n. 8, p. 1117-1124, 2014.

MOREIRA, H. J. C.; BRAGANÇA, H. B. N. Manual de identificação de plantas daninhas infestantes - cultivos de verão. Campinas: 2010. 642 p. 
STREIBIG, J. C. A method for determining the biological effect of herbicide mixtures. Weed Sci., v. 29, n. 4, p. 469-473, 1981.

TREZZI, M. M. et al. Antagonismo das associações de clodinafoppropargyl com metsulfuron methyl e 2,4-D no controle de azevém (Lolium multiflorum). Planta Daninha, v. 25, n. 4 , p. $839-847,2007$.
WAGGONER, B. S. et al. Control of glyphosate-resistant horseweed (Conyza canadensis) with saflufenacil tank mixtures in no-till cotton. Weed Technol., v. 25, n. 3, p. $310-315,2011$.

ZHANG, J. et al. Antagonism and synergism between herbicides: trends from previous studies. Weed Technol., v. 9 , n. 1, p. 86-90, 1995. 